\section{'Ben Lear' and 'Stevens' Cranberry Root and Shoot Growth Response to Soil Water Potential}

\author{
Dana L. Baumann, Beth Ann Workmaster, and Kevin R. Kosola ${ }^{1}$ \\ Department of Horticulture, University of Wisconsin, 1575 Linden Drive, \\ Madison, WI, 53706 \\ Additional index words. Vaccinium macrocarpon, minirhizotron, drought, flooding, root
demography, growth analysis
}

\begin{abstract}
Wisconsin cranberry growers report that fruit production by the cranberry cultivar 'Ben Lear' (Vaccinium macrocarpon Ait.) is low in beds with poor drainage, while the cultivar 'Stevens' is less sensitive to these conditions. We hypothesized that 'Ben Lear' and 'Stevens' would differ in their root growth and mortality response to variation in soil water potential. Rooted cuttings of each cultivar were grown in a greenhouse in sand-filled pots with three different soil water potentials which were regulated by a hanging water column below a fritted ceramic plate. A minirhizotron camera was used to record root growth and mortality weekly for five weeks. Root mortality was negligible $(2 \%$ to $6 \%)$. Whole plant relative growth rates were greatest for both cultivars under the wettest conditions. Rooting depth was shallowest under the wettest conditions. Whole-plant relative growth rates of 'Ben Lear' were higher than 'Stevens' at all soil water potentials. 'Stevens' plants had significantly higher root to shoot ratios and lower leaf area ratios than 'Ben Lear' plants, and produced more total root length than 'Ben Lear' at all soil water potentials. Shallow rooting, high leaf area ratio, and low allocation to root production by 'Ben Lear' plants may lead to greater susceptibility to drought stress than 'Stevens' plants in poorly drained cranberry beds.
\end{abstract}

Wisconsin cranberry growers indicate that fruit production by 'Ben Lear' cranberry ( Vaccinium macrocarpon Ait.) is low in beds with poor drainage. These beds will typically have high root zone water potential, with the resultant potential for low soil oxygen availability. 'Stevens' is less sensitive to these conditions, and typically has good yields in a wide range of conditions. Poor drainage in cranberry beds is known to inhibit establishment and growth of cranberry in the field (Chandler, 1952, 1953; McCown, personal communication). Based on these observations, we expected that rooting would be slower for 'Ben Lear' cuttings than for 'Stevens' cuttings in flooded conditions, due either to increased root mortality, slower root growth, or to a combination of both factors. We also expected that root turnover of cranberry roots could be very rapid. Cranberry lateral fine roots are called "hair roots" due to their small diameter and the lack of root hairs. Theory predicts that root lifespan should be shortest for small-diameter roots, due to their low construction costs (Eissenstat and Yanai, 1997). We are unaware of published data on cranberry root turnover.

The general implication of grower obser-

\footnotetext{
Received for publication 20 Sept. 2004. Accepted for publication 24 Oct. 2004. This work partially supported by UW Hatch funds and by the Robert and Helen Gottschalk Endowment. We thank Meghan Mclean and Erica Ramirez for help with minirhizotron image analysis, Shaminder Miranpuri for assistance with plant growth, and John Stier, Jim Busse, Bjorn Karlsson, and Kay Baergen for comments on the manuscript.

${ }^{1}$ To whom reprint requests should be addressed; e-mail kkosola@facstaff.wisc.edu.
}

vations is that 'Stevens' has a broader range of adaptability to extremes of soil water availability than 'Ben Lear', and that 'Stevens' roo growth and mortality would be less responsive to variation in soil water potential than 'Ben Lear'. To test these hypotheses, a greenhouse experiment was conducted to determine the optimum soil water potential for root growth of 'Ben Lear' and 'Stevens' cranberry. 'Stevens' is the most commonly grown cultivar in Wisconsin, although 'Ben Lear' is also widely planted as an early ripening cultivar with good color. We hypothesized that these two cranberry cultivars would differ in their root growth and mortality response to variation in soil water potential.

\section{Materials And Methods}

Experiments were conducted with rooted cuttings of cranberry, cv. 'Ben Lear' and cv.'Stevens' . Cuttings were collected near Babcock, WI from 4-year-old sand-substrate beds with good runner production. Vegetative cranberry vine cuttings $(10 \mathrm{~cm})$ were placed in deionized water to establish roots. After roots appeared (within about $10 \mathrm{~d}$ ) the water was replaced with a modified Hoagland's nutrient solution for cranberry and blueberry (Barak et al., 1996), and the culture vessel moved to a greenhouse with supplemental sodium lighting providing a fourteen hour day. Cuttings were allowed to develop for 6 weeks before transplanting into the experimental pots. Experiments were conducted in the same greenhouse used to start cuttings.

Experimental pots (Fig. 1) were built with a top section for plant growth and a bottom water reservoir. Each section was 15.24cm-high, 25.4-cm-diameter Schedule 40 PCV pipe. The two sections of the pot were separated by a porous ceramic plate (1 bar standard pore size, Soil Moisture, Inc., Santa Barbara, Calif.). The height of the hanging water column in the hose connected to the bottom water reservoir (Fig. 1) regulated water potential at the top surface of the ceramic plate (Hillel, 1982). Water column height for the high water table treatment was $2.5 \mathrm{~cm}$ above the ceramic plate. The medium and low water table treatments were 23 and $41 \mathrm{~cm}$ below the ceramic plate. The pots were filled with $10 \mathrm{~cm}$ of autoclaved, medium textured sand $(0.8 \%$

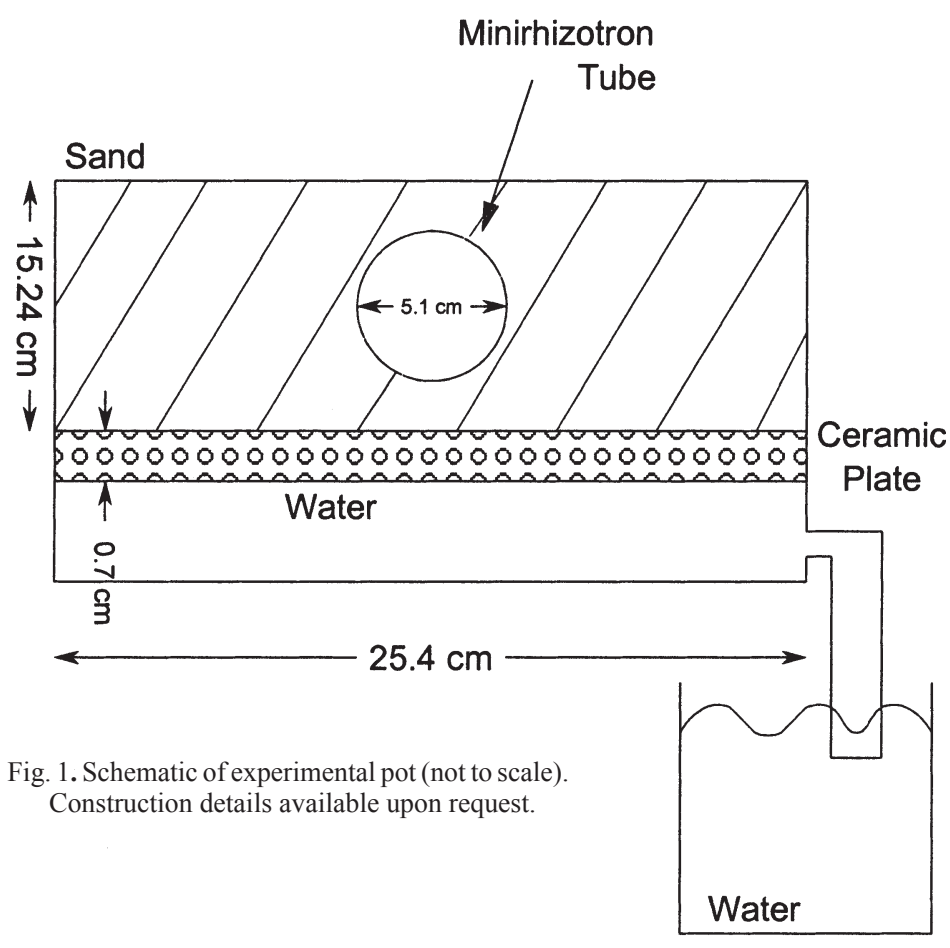


Table 1. Whole-plant growth analysis for 'Ben Lear' and 'Stevens' cranberry plants grown at high $\left(\Psi_{\text {soil }}=0 \mathrm{Mpa}\right.$, water table $2.5 \mathrm{~cm}$ above plate), medium $\left(\Psi_{\text {soil }}=\right.$ $-0.234 \mathrm{kPa}$, water table $23 \mathrm{~cm}$ below plate), and low $\left(\Psi_{\text {soil }}=-0.418 \mathrm{kPa}\right.$, water table $41 \mathrm{~cm}$ below plate) water levels. All weight measurements were based on a dry weight basis. Relative growth rate (RGR; $\left.\mathrm{g} \cdot \mathrm{g}^{-1} \cdot \mathrm{d}^{-1}\right)$ was based on dry weight gain between planting and harvest. Root length at harvest (m) was determined with WinRHIZO analysis of a scanned subsample. Values are mean $\pm \mathrm{SE}, \mathrm{n}=5$ for all data.

\begin{tabular}{|c|c|c|c|c|c|c|c|c|c|c|}
\hline \multirow{2}{*}{$\begin{array}{l}\text { Water } \\
\text { table } \\
\text { ht } \\
(\mathrm{cm}) \\
\end{array}$} & \multicolumn{2}{|c|}{$\begin{array}{c}\text { Whole- } \\
\text { plant } \\
\text { RGR } \\
\left(\mathrm{g} \cdot \mathrm{g}^{-1} \cdot \mathrm{d}^{-1}\right)\end{array}$} & \multicolumn{2}{|c|}{$\begin{array}{c}\text { Root to } \\
\text { shoot } \\
\text { ratio } \\
\left(\mathrm{g}_{\text {root }} / \mathrm{g}_{\text {shoot }}\right)\end{array}$} & \multicolumn{2}{|c|}{$\begin{array}{c}\text { Root } \\
w t \\
\text { ratio } \\
\left(\mathrm{g}_{\text {root }} / \mathrm{g}_{\text {plant }}\right)\end{array}$} & \multicolumn{2}{|c|}{$\begin{array}{c}\text { Leaf } \\
\text { area } \\
\text { ratio } \\
\left(\mathrm{cm}_{\text {leaf }}^{2} / \mathrm{g}_{\text {plant }}\right)\end{array}$} & \multicolumn{2}{|c|}{$\begin{array}{l}\text { Root } \\
\text { length at } \\
\text { harvest } \\
\text { (m) }\end{array}$} \\
\hline & Ben Lear & Stevens & Ben Lear & Stevens & Ben Lear & Stevens & Ben Lear & Stevens & Ben Lear & Stevens \\
\hline 2.5 & $0.026 \pm 0.002$ & $0.024 \pm 0.001$ & $0.20 \pm 0.03$ & $0.30 \pm 0.03$ & $0.16 \pm 0.02$ & $0.22 \pm 0.02$ & $3.22 \pm 0.25$ & $2.45 \pm 0.13$ & $24.0 \pm 0.95$ & $51.9 \pm 0.98$ \\
\hline-23 & $0.023 \pm 0.001$ & $0.017 \pm 0.002$ & $0.20 \pm 0.03$ & $0.38 \pm 0.10$ & $0.21 \pm 0.02$ & $0.24 \pm 0.04$ & $2.81 \pm 0.25$ & $1.46 \pm 0.27$ & $28.7 \pm 0.58$ & $35.6 \pm 0.50$ \\
\hline-41 & $0.020 \pm 0.001$ & $0.018 \pm 0.001$ & $0.27 \pm 0.03$ & $0.27 \pm 0.02$ & $0.21 \pm 0.02$ & $0.20 \pm 0.01$ & $2.39 \pm 0.25$ & $1.70 \pm 0.15$ & $17.6 \pm 0.45$ & $37.4 \pm 0.80$ \\
\hline
\end{tabular}

Table 2. Results fromANOVA(Proc MIXED, denominator degrees of freedom adjusted with Kenward-Roger procedure). Values are F values, subscripted with numerator and denominator degrees of freedom.

\begin{tabular}{|c|c|c|c|}
\hline Parameter & Cultivar & $\begin{array}{l}\text { Water } \\
\text { table ht }\end{array}$ & $\begin{array}{c}\text { Cultivar } \times \\
\text { water } \\
\text { table ht }\end{array}$ \\
\hline Whole-plant relative growth rate & $6.07_{154}^{*}$ & $6.93_{254}{ }^{* * *}$ & $0.63_{254}$ \\
\hline Root to shoot ratio & $4.17_{1,44 *}^{1,54}$ & $0.59_{2,44}^{2,54}$ & $1.63_{2,44}^{2,34}$ \\
\hline Root weight ratio & $4.29_{1,45}$ & $0.62_{2,45}^{2,44}$ & $1.61_{2,45}^{2,44}$ \\
\hline Leaf area ratio & $30.0_{1,25}$ & $7.38_{2,25}^{2,45}$ & $1.15_{2,25}^{2,45}$ \\
\hline Harvested root length & $19.15_{1.51}^{* * * *}$ & $1.40_{2.51}^{2,23}$ & $2.56_{2.51}^{2,3}$ \\
\hline
\end{tabular}

*,**,***,***** Significant at $P \leq 0.05 ; 0.01,0.001$, or 0.0001 , respectively.

gravel and very coarse sand, $15.9 \%$ coarse sand, $77.4 \%$ medium sand, $5.6 \%$ fine sand, $0.3 \%$ very fine and silt; particle classifications from U.S. Soil Conservation Service, 1993) collected from the sand pile at a commercial cranberry marsh. Based on the soil moisture release curve for this sand (data not shown), the gravimetric water content at the surface in the high water table treatment was between $10 \%$ and $20 \%$ soil moisture. Soil water content in the other treatments was $<1 \%$.

Four rooted cuttings were planted in each pot, two on each side of the minirhizotron tube. Plants were watered in at planting with $200 \mathrm{~mL}$ of the modified Hoagland's solution, covered with a clear plastic bag, and misted daily to increase humidity and reduce transplant mortality. The plastic bags were removed after 1 week. To mimic conditions in a new cranberry bed, we established cranberry plants for 3 weeks at a medium (23 $\mathrm{cm}$ below ceramic plate, $-0.23 \mathrm{kPa}$ ) water potential before treatments were applied. Allowing plants to establish at this water table height encouraged development of a more extensive root system, allowing them to better cope with water stress applied later on. This is similar to grower practices for enhancing deeper rooting.

The entire root system of each plant was scanned before planting to determine initial root length using WinRHIZO (Reagent Instrument Inc., Quebec, Canada). Fine root production and mortality measurements were made as described by Hendrick and Pregitzer (1993). Minirhizotron images were captured weekly for 5 weeks (Bartz Technology Inc., I-CAP software, Santa Barbara, Calif.). The length and diameter of each individual root segment at each observation date were measured using RooTracker software (Duke University, Durham, N.C.). A root was classified dead when it became very faint or discontinuous, shriveled to $\leq 10 \%$ of its previous diameter, or disappeared entirely.

Plants were harvested 5 weeks after start- ing the treatments ( 8 weeks after transplanting into the pots). At harvest, the pot was filled with water to loosen the sand and allow removal of the intact plant. Roots were lightly agitated under water until they were free of sand particles. After patting the roots dry with a paper towel and cutting them from the stem, total root fresh weight was recorded and a subsample (average fresh weight 35 $\mathrm{mg}$ ) collected and weighed for root length measurements.

Subsampling for root length measurement was necessary due to the extraordinary root length and very small diameter of cranberry roots; WinRHIZO was unable to distinguish individual roots when the entire root mass was scanned. Root length subsamples were stored in $50 \%$ ethanol in glass scintillation vials for 1 week before measurements. Before scanning, roots were rinsed in deionized water and immersed in neutral red staining solution $\left(0.5 \mathrm{~g} \cdot \mathrm{L}^{-1}\right)$ for $24 \mathrm{~h}$ (Bouma et al., 2000); roots were destained by rinsing in deionized water. Stained roots were cut into pieces about $1 \mathrm{~cm}$ long and placed in a Plexiglas tray $(20 \times 30 \mathrm{~cm})$ with sufficient water to float the roots. Root measurements were collected by scanning and analysis with the program WinRHIZO. We obtained the best imaging of individual cranberry roots by using the maximum scanning resolution (800 dpi) with Lagarde's method (WinRHIZO). Total length of the harvested roots was estimated based on the proportion of subsample root fresh weight to total root fresh weight at time of harvest.

To obtain an estimate of initial plant weight for calculation of whole-plant relative growth rate $[\mathrm{RGR}=(\ln$ final dry weight $-\ln$ initial dry weight)/time] (Hunt, 1982), we measured the diameter and length of the rooted cuttings at the time of transplanting. A set of twenty cuttings of each cultivar was dried and weighed at this time. There was a strong linear relationship between estimated stem volume (assuming the plant approximated a cylinder) and dry weight (Ben Lear $r^{2}=0.82$,
Stevens $\left.r^{2}=0.83\right)$. By using the measurements of plant size at transplanting to estimate initial weight, our RGR estimates include growth for the entire 8 weeks after transplanting, rather than only the 5-week treatment period. They are therefore likely to underestimate treatment effects on RGR.

The experiment was conducted as a randomized complete block design with five replications. Statistical analysis of cranberry variety and water effects on fine root biomass, whole-plant RGR, leaf area ratio, root weight ratio, root to shoot ratio and root length production was conducted with SAS Proc Mixed (SAS Institute, Cary, N.C.). Blocks were random variables and cultivar and water table level were fixed variables. The normality of frequency distribution for each variable was checked with SAS Proc Univariate. Root to shoot ratio data were transformed with the arcsine square root transformation to obtain normality before analysis; all other data were normally distributed. Repeated measures ANOVA in SAS Proc Mixed was used to analyze root length growth and RGR from the minirhizotron measurements.

\section{Results}

Observations during harvest indicated that root angle and rooting depth varied among the three water potential treatments. Plants growing in the high water table treatment produced shallow, wide spreading roots with extensive development at the soil surface, and no root growth below about $2 \mathrm{~cm}$ deep. Roots in the low water table treatment grew straight down, wrapping underneath the minirhizotron tube. Roots in the intermediate water table treatment were intermediate in root angle, and could be found throughout the soil profile.

'Ben Lear' whole-plant RGR $\left(\mathrm{g} \cdot \mathrm{g}^{-1} \cdot \mathrm{d}^{-1}\right)$ was higher than 'Stevens' whole-plant RGR at all water potentials (Tables 1 and 2). Wholeplant RGR was greatest for both cultivars at the highest water potential (Tables 1 and 2).

'Stevens' cumulative root length production and root length RGR on minirhizotron tubes was significantly greater than that of 'Ben Lear' over the course of the experiment (Fig. 2, Table 3). 'Ben Lear' root length RGRs were lower than for 'Stevens' at all three water levels (Fig. 2A). Root length RGR for both cultivars increased significantly during the experiment (Fig. 2B, Table 3). 'Stevens' produced significantly more total root length (measured at harvest) than 'Ben Lear' at all water potentials (Tables 1 and 2). Final 


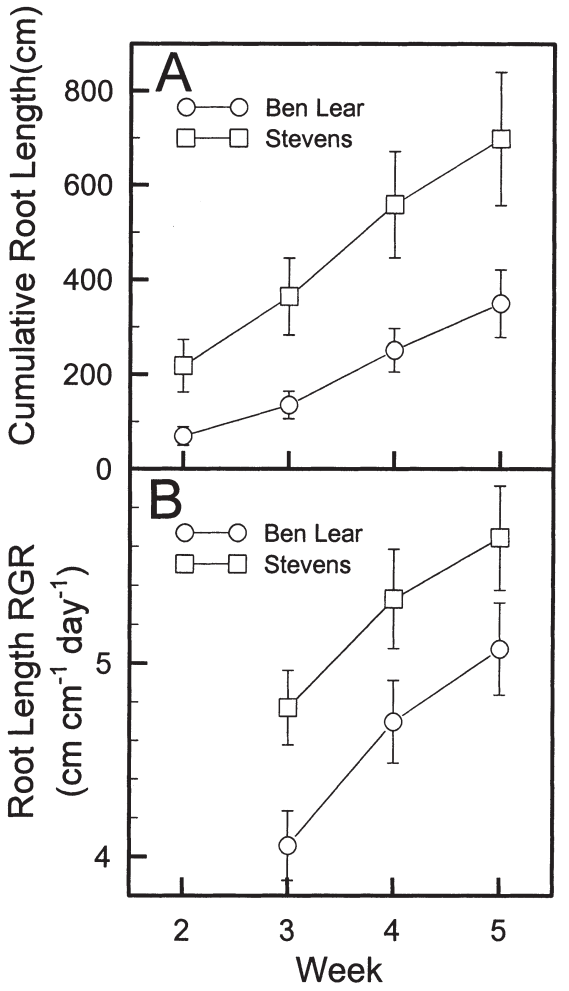

Fig. 2. (A) Cumulative root length (cm) and (B) root length relative growth rate $\left(\mathrm{cm} \cdot \mathrm{cm}^{-1} \cdot \mathrm{d}^{-1}\right)$ measured per pot on minirhizotron tubes for 'Ben Lear' and 'Stevens' cultivars over 5 weeks, averaged over all water table treatments. Cultivar effects were significant for cumulative root length and relative growth rate; time effects were significant for relative growth rate (Table $3)$. Error bars are \pm standard error.

root lengths per plant ranged from $17 \mathrm{~m}$ for 'Ben Lear' growing in the lowest soil water potential to $52 \mathrm{~m}$ for 'Stevens' growing in the highest soil water potential (Table 1).

Root to shoot ratio and root weight ratio (root weight/whole plant weight) were greater for 'Stevens' plants than for 'Ben Lear' plants at all water potentials (Tables 1 and 2). Leaf area ratio (leaf area/whole plant weight) was higher for 'Ben Lear' than for 'Stevens' at all water potentials (Tables 1 and 2).

The fine root diameter distribution of both cultivars was strongly skewed to the right (Fig. 3). Root diameter was not significantly affected by any treatment, and did not differ significantly between the two cultivars (average diameter of $0.046 \mathrm{~mm}$ for 'Stevens' and $0.050 \mathrm{~mm}$ for 'Ben Lear'). Root mortality was negligible ( $2 \%$ to $6 \%$ over 5 weeks) for both cultivars at all water potential levels (data not shown).

\section{Discussion}

'Ben Lear' and 'Stevens' cultivars exhibited fundamental differences in growth and carbon allocation. 'Ben Lear' grew faster, and had greater allocation to leaves, while 'Stevens' grew slower, and produced more total root length; differences were most pronounced at high water potentials (about $0 \mathrm{Mpa}$ ). The root system distribution of both

Table 3. Results from repeated measures ANOVA for the effects of week, cultivar, and water table height on total cumulative root length $(\mathrm{cm})$ and on root length relative growth rate $\left(\mathrm{RGR} ; \mathrm{cm} \cdot \mathrm{cm}^{-1} \cdot \mathrm{d}^{-1}\right)$ over 5 weeks on minirhizotron tube. Initial root length is used as a covariate for analysis of cumulative root length.

\begin{tabular}{|c|c|c|}
\hline Effect & $\begin{array}{c}\text { Total } \\
\text { cumulative } \\
\text { root length } \\
(\mathrm{cm}) \\
\text { F value }\end{array}$ & $\begin{array}{c}\text { Root } \\
\text { length } \\
\text { RGR } \\
\left(\mathrm{cm} \cdot \mathrm{cm}^{-1} \cdot \mathrm{d}^{-1}\right) \\
\text { F value }\end{array}$ \\
\hline Observation date & $1.83_{3,35}$ & $80.36_{232}{ }^{* * * * *}$ \\
\hline Cultivar & $9.92^{3,35 * *}$ & $4.53_{123}^{2,32} *$ \\
\hline Cultivar $\times$ observation date & $0.89,3,16$ & $0.37_{2,32}^{1,23}$ \\
\hline Water & $0.63_{2,13}^{3,35}$ & $0.23_{2,23}^{2,32}$ \\
\hline Observation date $\times$ water & $0.37_{6,41}^{2,13}$ & $0.44_{4,35}^{2,23}$ \\
\hline Cultivar $\times$ water & $1.74_{2,13}^{0,41}$ & $1.23_{2,23}^{4,30}$ \\
\hline Cultivar $\times$ observation date $\times$ water & $0.23_{6,41}^{2,13}$ & $0.15_{4,35}^{2,23}$ \\
\hline Initial root length & $1.48_{1.23}$ & \\
\hline
\end{tabular}

${ }^{*, * * *, * * * * * * * * *}$ Significant at $P \leq 0.05 ; 0.01,0.001$, or 0.0001 , respectively.

cultivars in the different treatments at harvest was similar to that described by Hall (1971), with the deepest rooting in the driest soil. RGRs and total root length accumulation for both cultivars were greatest in the high water potential treatment. This is noteworthy, given grower concerns about the requirements of 'Ben Lear' for good soil drainage; both cultivars seem to grow well with a constant high water table. The positive relationship between whole-plant RGR and leaf area ratio, and the negative relationship between wholeplant RGR and root weight ratio is consistent with predictions of functional balance in plant carbon allocation, where increased allocation to root biomass reduces the potential for photosynthetic carbon gain by reducing potential leaf area (Brouwer and DeWit, 1969; Poorter and Lambers, 1991).

Despite our expectations, we found little effect of soil water availability on root mortality. Since the lifespan of cranberry roots was unknown, a sampling period of 1 week was used to minimize overestimation of lifespan due to the appearance and disappearance or roots between sampling periods (Hendrick and Pregitzer, 1996; Tingey et al., 2003). Smallerdiameter roots are expected to be shorter lived than larger diameter roots (Eissenstat, 1992). Although cranberry root diameter was extremely small compared to fine roots of other non-Ericaceous woody plants, it was noteworthy that little mortality occurred within the 5-week study. Longer observations will be needed to determine environmental effects on the lifespan of cranberry roots.

Our study did not address the potential role of root pathogens in reducing plant growth in poorly drained fields. In contrast to Wisconsin grower observations, Massachussetts cranberry growers observe that 'Stevens' grows worse than 'Ben Lear' under poorly drained conditions (DeMoranville, personal communication). Greater root system damage to 'Stevens' than 'Ben Lear' by pathogens (e.g., phytophthora root rot) may be responsible for this difference among regions. Phytophthora root rot is common in Massachussetts and New Jersey cranberry beds (Oudemans, 1999), but is rarely detected in Wisconsin (McManus, personal communication).

We observed rapid growth of 'Ben Lear' in pots with a stable, extremely high water table. How can this observation be reconciled with grower observations of 'Ben Lear' problems with wet feet? A combination of factors is likely to be involved. Based on our observations of shallow root growth in the highest water table treatment, cranberries growing in poorly drained fields are likely to have shallow root systems, as well as low carbon allocation to roots. As most Wisconsin cranberry beds are either on a sand substrate, or were constructed with a sand layer on top of peat, slight changes in water table height are likely to have large effects on root zone water content. Any subsequent lowering of the water table would expose shallow-rooted plants established in poorly drained beds to water stress. Given the greater leaf area ratio and lower root growth potential, for 'Ben Lear' than for 'Stevens', 'Ben Lear' plants are likely to both transpire more and have a lower capacity to acquire water than 'Stevens' plants. These growth patterns are likely to make 'Ben Lear' more susceptible than 'Stevens' plants to water stress under a fluctuating water table. Field observations of root growth and plant water relations are required to determine if the differences between the two cultivars in root allocation explain grower observations of lower yield of 'Ben Lear' in poorly drained beds in Wisconsin.

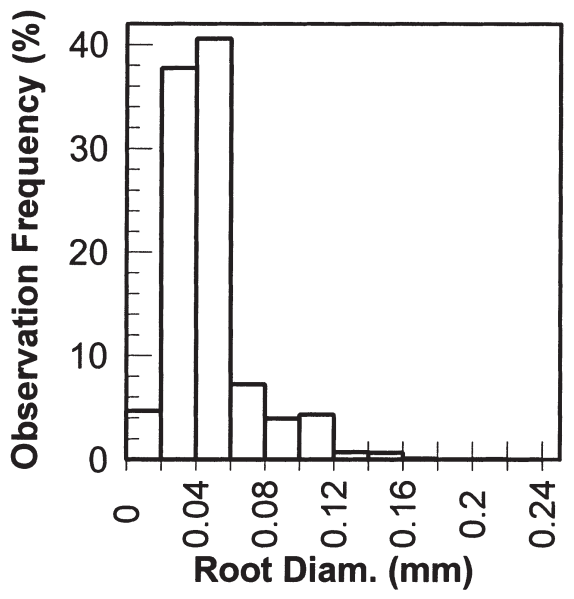

Fig. 3. Histogram of root diameter ( $\mathrm{mm}$ ) measured on minirhizotron tube at week 5; includes both 'Ben Lear' and 'Stevens' at all water tables, as neither cultivar or water table treatment had a significant effect on root diameter. Total observations $=7,439$ roots. Observation frequencies for roots $>0.16 \mathrm{~mm}$ diameter are $<0.1 \%$. 


\section{Literature Cited}

Barak, P., J.D. Smith, A.R. Krueger, and L.A. Peterson. 1996. Measurement of short-term nutrient uptake rates in cranberry by aeroponics. Plant Cell Environ. 19:237-242.

Bouma, T.J., K.L. Nielsen, and B. Koutstaal. 2000. Sample preparation and scanning protocol for computerised analysis of root length and diameter. Plant Soil 218:185-196.

Brouwer, R. and C.T. DeWit. 1969. A simulation model of plant growth with special attention to root growth and its consequences, p. 224-244. In: W.J. Whittington (ed.). Proceedings of the fifteenth Easter school in agricultural science. Butterworths, London.

Chandler, F.B. 1952. Poor draining peat. Cranberries 17:6-7.
Chandler, F.B. 1953. Drainage. Cranberries 18:17-18.

Eissenstat, D.M. 1992. Costs and benefits of constructing roots of small diameter. J. Plant Nutr. 15:763-782.

Eissenstat, D.M. and R.D. Yanai. 1997. The ecology of root lifespan. Adv. Ecol. Res. 27:1-60.

Hall, I.V. 1971. Cranberry growth as related to water levels in the soil. Can. J. Plant Sci. 51:237-238.

Hendrick, R.L. and K.S. Pregitzer. 1993. Patterns of fine root mortality in two sugar maple forests. Nature 361:59-61.

Hendrick, R.L. and K.S. Pregitzer. 1996. Applications of minirhizotrons to understand root function in forests and other natural ecosystems. Plant Soil 185:293-304.
Hillel, D. 1982. Introduction to soil physics. Academic Press, New York.

Hunt, R. 1982. Plant growth curves. The functional approach to plant growth analysis. E. Arnold, London.

Oudemans, P.V. 1999. Phytophthora species associated with cranberry root rot and surface irrigation water in New Jersey. Plant Dis. $83: 251-258$.

Poorter, H. and H. Lambers. 1991. Is interspecific variation in relative growth rate positively correlated with biomass allocation to the leaves? Am. Nat. 138:1264-1268.

Tingey, D.T., D.L. Phillips, and M.G. Johnson. 2003. Optimizing minirhizotron sample frequency for an evergreen and deciduous tree species. New Phytol. 157:155-161. 